\title{
Study Primary Purpose
}

National Cancer Institute

\section{Source}

National Cancer Institute. Study Primary Purpose. NCI Thesaurus. Code C147141.

The principal reason or intention for the execution of an interventional or non-

interventional clinical study. 